\title{
Government-subsidized restaurants in Brazil: an evaluation within the framework of food and nutrition security
}

\author{
Restaurantes populares brasileiros: \\ avaliação no âmbito da segurança \\ alimentar e nutricional
}

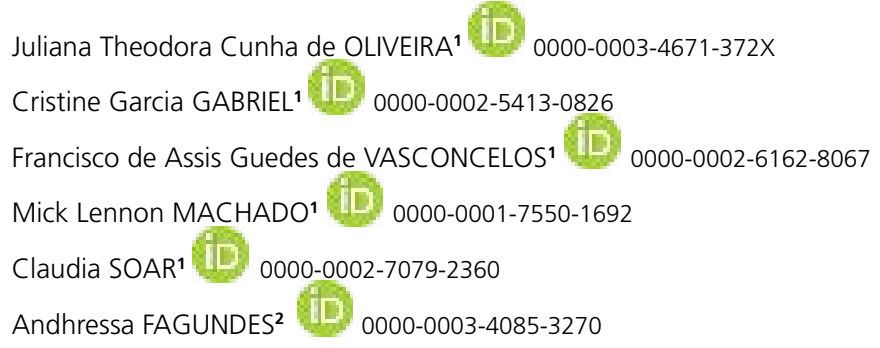

A B S T R A C T

\section{Objective}

The objective was to evaluate government-subsidized restaurants in southern Brazil according to current regulations and the National Food and Nutrition Security Policy.

\footnotetext{
1 Universidade Federal de Santa Catarina, Departamento de Nutrição, Programa de Pós-Graduação em Nutrição. Campus Universitário Reitor João David Ferreira Lima, R. Eng. Agronômico Andrei Cristian Ferreira, s/n., Trindade, 88040-900, Florianópolis, SC, Brasil. Correspondence to: J.T.C. OLIVEIRA. E-mail: <juliana.theodora@yahoo.com.br>.

2 Universidade Federal de Sergipe, Departamento de Nutrição, Programa de Pós-Graduação em Nutrição. Sergipe, SE, Brasil.

Article elaborated from the thesis by J.T.C. OLIVEIRA, entitled "Avaliação dos restaurantes populares no âmbito da segurança alimentar e nutricional”. Universidade Federal de Santa Catarina; 2018.

Support: This research was funded by the Secretaria Nacional de Segurança Alimentar e Nutricional (SESAN, Food and Nutrition Security Department) / Ministério do Desenvolvimento Social (MDS, Ministry of Social Development). Public notice \#01/2013.
}

\section{How to cite this article}

Oliveira JTC, Gabriel CG, Vasconcelos FAG, Machado ML, Soar C, Fagundes A. Government-subsidized restaurants in Brazil: an evaluation within the framework of food and nutrition security. Rev Nutr. 2020;33:e200085. https://doi. org/10.1590/1678-9865202033e200085 


\section{Methods}

An evaluation matrix was developed on the basis of a literature review, logic model, immersion in a government-subsidized restaurant, and workshops with experts in the field. The Government-Subsidized Restaurant Evaluation Matrix contemplates two dimensions: Political/Organizational, composed of the subdimensions Administration, Structure, and Target Groups; and Technical/Operational, composed of the subdimensions Meal Quality, Food and Nutrition Education, and Extended Social Support. Subdimensions comprised 24 indicators. Data were gathered through an online survey of the 35 government-subsidized restaurants operating in southern Brazil.

\section{Results}

Of the 35 government-subsidized restaurants in southern Brazil, 86\% $(n=30)$ participated in the study. Meal Quality and Administration received the highest score in $73 \%$ and $60 \%$ of government-subsidized restaurants, respectively, whereas Food and Nutrition Education and Extended Social Support received the lowest score in $47 \%$ and $40 \%$, respectively.

\section{Conclusion}

Advances are needed in the understanding of government-subsidized restaurants as public facilities for ensuring food and nutrition security and the human right to adequate food.

Keywords: Food and nutrition security. Public policy. Restaurants.

\section{R E S U M O}

\section{Objetivo}

O objetivo do estudo foi avaliar os restaurantes populares da região Sul do Brasil utilizando como parâmetros as diretrizes e normativas em vigor e a Política Nacional de Segurança Alimentar e Nutricional.

\section{Métodos}

Avaliação do tipo normativa. Para isso, foi utilizada a Matriz Avaliativa elaborada por meio das seguintes etapas: revisão sistematizada; elaboração do Modelo Teórico-Lógico; processo de imersão em um restaurante popular e oficinas de consenso com especialistas na temática. A matriz avaliativa contempla duas dimensões: Político-Organizacional, organizada nas subdimensões Administração, Estrutura e Público Frequentador; e Técnico-Operacional, organizada nas subdimensões Alimentação Adequada, Educação Alimentar e Nutricional e Assistência Ampliada ao Público Frequentador. Foram elencados 24 indicadores, coletados por meio de questionário online respondido pelos gestores dos restaurantes.

\section{Resultados}

Dos 35 restaurantes existentes na região Sul, 86\% (30) participaram da pesquisa. As subdimensões mais bem avaliadas foram Alimentação Adequada e Administração, com 70\% e 63\% dos restaurantes avaliados como "bom", respectivamente. As subdimensões com piores avaliações foram Educação Alimentar e Nutricional e Assistência Ampliada ao Usuário, com 47\% e 40\% dos restaurantes classificados como "ruim", respectivamente.

\section{Conclusão}

Destaca-se a boa avaliação dos itens referentes à administração, estrutura e ao processo de produção de refeições, em detrimento aos aspectos relacionados à garantia dos direitos dos usuários.

Palavras-chave: Segurança alimentar e nutricional. Política pública. Restaurantes.

\section{INTRODUCTION}

Food insecurity, or the lack of access to adequate food, reduced from $18.6 \%$ in 1990-1992 to $10.9 \%$ in 2014-2016, reflecting a significant decrease in the number of people suffering from hunger worldwide. Nevertheless, despite advances in the global fight against hunger and malnutrition, it is estimated that 821 million people still suffer from such conditions [1]. Throughout history, various initiatives have been implemented to provide free or low-cost meals for vulnerable populations. For 
instance, Canada provides free food for low-income and food-insecure people [2]. In the United States of America, soup kitchens target people experiencing homelessness [3], and in Spain, soup kitchens target those experiencing food insecurity [4]. In Mexico, community kitchens have been proposed as a strategy to improve the social conditions and food security of no-income, marginalized people [5]. In Peru, community kitchens provide subsidized meals for low-income people as part of a national economic and nutritional development program [6]. Such initiatives have different levels of stability; some are established based on public policies, whereas others are temporary programs to aid specific groups. These efforts are designed to reduce social and economic inequality by providing access to sufficient amounts of nutritious food [7].

In Brazil, Government-Subsidized Restaurants (GSR) emerged in the 1930s to support social security contributors. In 2003, GSR were included in the national program Zero Hunger [8]. From 2006, with the Organic Law of Food and Nutrition Security (LOSAN), some food and nutrition public programs, such as GSR and Food Banks, became essential strategies for fulfilling the human right to adequate food [7]. Therefore, Brazilian GSR are not isolated strategies; instead, they are part of complex and comprehensive public policies that integrate the Brazilian National Food and Nutrition Security Policy (PNSAN) [9]. GSR aim to increase the offer of healthy meals at affordable prices to food-insecure individuals with low purchasing power, in addition to being multipurpose spaces for social development activities and generation of employment and income, thereby strengthening citizenship [10].

Because GSR are valuable tools for improving food and nutrition security indices [8], it is crucial to evaluate and monitor their quality and results for the population [11]. Few studies have evaluated GSR as strategies to promote food and nutrition security and the right to food, characterizing a research gap $[11,12]$. Data indicate that $22.6 \%$ of Brazilian households experienced some degree of food insecurity in 2014 [13]. The country ranks 79 th in Human Development Index (HDI) among the 188 countries listed. Among Mercosur countries, Brazil occupies the penultimate position, ranking higher than Paraguay only. Brazil's inequality is higher than the Latin American average, according to the inequality-adjusted Human Development Index score. These indices justify the importance of studies focused on improving and expanding food and nutrition security strategies, such as GSR, and the health conditions of the population. The aim of this study was to evaluate GSR in southern Brazil.

\section{METHODS}

In this cross-sectional study, we assessed the performance of GSR in southern Brazil using, as parameters, the guidelines and regulations in force and the National Food and Nutrition Security Policy $[10,11]$. The number of GSR was obtained from the Brazilian Institute of Geography and Statistics and the 2015 Food and Nutrition Security Survey $[9,13]$. The sample included all 35 GSR in operation in the states of Paraná, Santa Catarina, and Rio Grande do Sul (Southern Brazil) in October 2017.

Detailed information on the development of the evaluation matrix is presented elsewhere [11]. Briefly, the matrix was elaborated in six stages: (1) systematic review of the literature; (2) immersion experience; (3) construction of the preliminary theoretical-logical model; (4) consensus workshops using the committee technique; (5) elaboration of the evaluation matrix; and (6) consensus with specialists in the field and in the implementation and management of GSR. Among the advantages 
of immersion, the researchers highlight the possibility of comparing theoretical data with reality, as well as visualizing unexpected facts. From the immersion, it was possible to verify whether the theoretical-logical model and the evaluation matrix presented the appropriate similarity with the object of study [11].

The matrix contemplates two dimensions: Political/Organizational, with the subdimensions Management and Structure and Target Public; and Technical/Operational, comprising the subdimensions Adequate Food, Food and Nutrition Education, and Extended Public Assistance. Twenty-four indicators and 29 measures were listed [11]. Table 1 shows the dimensions, subdimensions, and indicators of the Government-Subsidized Restaurant Evaluation Matrix and their scoring criteria.

Questions were formulated to address each indicator of the Government-Subsidized Restaurant Evaluation Matrix. The possible answers to each question were "good", "fair", or "poor" (Table 2). This method of classification is standard in the field of health care research [5]. Data collection was performed from October to December 2017.

Data were subjected to absolute and relative frequency distribution analysis. All indicators were attributed the same weight. Variables classified as good by participants were attributed a score of 10 , those ranked as fair were attributed a score of 5 , and those classified as poor were given a score of 0 . The indicator score is the mean score of its respective variables, the subdimension score is the mean score of its indicators, and the dimension score is the mean score of its subdimensions. Indicator, subdimension, dimension, and overall scores were categorized as good when above 7.0, fair when between 7.0 and 5.0, and poor when below 5.0 [5]. All participants signed an informed consent form. This study was approved by the Human Research Ethics Committee of the Federal University of Santa Catarina, Brazil (protocol 1.160.850).

\section{RE S U L T S}

Of the 35 GSR in operation in Southern Brazil, 30 (86\%) answered the questionnaire: 4 (100\%) from Santa Catarina, 12 (83\%) from Rio Grande do Sul, and 15 (79\%) from Paraná. In total, $57 \%$ of the GSR were under municipal management, 30\% under outsourced management, and $13 \%$ under a mixed management system. The majority of respondents were technically responsible dietitians or nutritionists (47\%), followed by coordinators (17\%), managers (13\%), and contract inspectors (10\%). Most GSR (73\%) were created between 2003 and 2010; of these, the majority (43\%) was inaugurated between 2003 and 2006. In total, 40\% of the GSR had a good overall score (Table 2).

Indicator and subdimension scores are presented in Table 2. The highest-ranked indicator was Financial Resources (I3), on which $100 \%$ of GSR received a good score, followed by Location (I8) (97\%), Food Safety (114) (93\%), and Physical Structure (19) (90\%). The worst-performing indicators were Maintenance (110), on which none of the GSR ranked as good, followed by Socialization Activities (I22) (7\%) and Availability (I1) (10\%).

Among the indicators of the subdimension Administration (S1), the highest scores were recorded for Financial Resources (I3), with 100\% of the GSR classified as good, and Quality Assessment and Monitoring (17), with $87 \%$ of good scores. The worst indicator was Articulation with other Food and Nutrition Security Programs (I5), on which $40 \%$ of the establishments had poor performance (Table 2). 
Table 1. Scoring table for evaluation of government-subsidized restaurants within the framework of food and nutrition security policies. Florianópolis (SC), Brazil, 2020.

\begin{tabular}{|c|c|c|c|c|c|}
\hline \multirow{2}{*}{ Dimension } & \multirow{2}{*}{ Subdimension/Indicator } & \multicolumn{4}{|c|}{ Score } \\
\hline & & Indicator & Subdimension & Dimension & Overall \\
\hline \multirow{15}{*}{$\begin{array}{l}\text { D1. Political/ } \\
\text { Organizational }\end{array}$} & S1. Management & & \multirow{8}{*}{$\begin{array}{l}\text { Mean of indicator scores: } \\
10-7=\text { good } \\
7-5=\text { fair } \\
5-0=\text { poor }\end{array}$} & \multirow{15}{*}{$\begin{array}{l}\text { Mean of } \\
\text { subdimension } \\
\text { scores: } \\
\text { 10-7= good } \\
7-5=\text { fair } \\
5-0=\text { poor }\end{array}$} & \multirow{15}{*}{$\begin{array}{l}\text { Mean of } \\
\text { dimension } \\
\text { scores: } \\
10-7=\text { good } \\
7-5=\text { fair } \\
5-0=\text { poor }\end{array}$} \\
\hline & 11. Availability & \multirow{4}{*}{$\begin{aligned} 10 & =\text { good } \\
5 & =\text { fair } \\
0 & =\text { poor }\end{aligned}$} & & & \\
\hline & 12. Human Resources & & & & \\
\hline & 13. Financial Resources & & & & \\
\hline & 14. Meal Price & & & & \\
\hline & $\begin{array}{l}\text { 15. Articulation with other Food } \\
\text { and Nutrition Security Programs }\end{array}$ & $\begin{aligned} 10 & =\text { good } \\
0 & =\text { poor }\end{aligned}$ & & & \\
\hline & 16. Waste Management & $\begin{aligned} 10 & =\text { good } \\
5 & =\text { fair } \\
0 & =\text { poor }\end{aligned}$ & & & \\
\hline & $\begin{array}{l}\text { 17. Quality Assessment and } \\
\text { Monitoring }\end{array}$ & $\begin{aligned} 10 & =\text { good } \\
0 & =\text { poor }\end{aligned}$ & & & \\
\hline & S2. Structure & & \multirow{4}{*}{$\begin{array}{l}\text { Mean of indicator scores: } \\
10-7=\text { good } \\
7-5=\text { fair } \\
5-0=\text { poor }\end{array}$} & & \\
\hline & 18. Location & $\begin{aligned} 10 & =\text { good } \\
0 & =\text { poor }\end{aligned}$ & & & \\
\hline & 19. Physical Structure & $\begin{array}{l}10=\text { good } \\
5=\text { fair } \\
0=\text { poor }\end{array}$ & & & \\
\hline & 110. Maintenance & $\begin{aligned} 10 & =\text { good } \\
0 & =\text { poor }\end{aligned}$ & & & \\
\hline & S3. Target Groups & & \multirow{3}{*}{$\begin{array}{l}\text { Mean of indicator scores: } \\
10-7=\text { good } \\
7-5=\text { fair } \\
5-0=\text { poor }\end{array}$} & & \\
\hline & 111. Users & $10=$ good & & & \\
\hline & $\begin{array}{l}\text { 112. Prioritization of Specific } \\
\text { Populations }\end{array}$ & $0=$ poor & & & \\
\hline \multirow{15}{*}{$\begin{array}{l}\text { D2. Technical/ } \\
\text { Operational }\end{array}$} & S4. Meal Quality & & \multirow{7}{*}{$\begin{array}{l}\text { Mean of indicator scores: } \\
10-7=\text { good } \\
7-5=\text { fair } \\
5-0=\text { poor }\end{array}$} & \multirow{15}{*}{$\begin{array}{l}\text { Mean of } \\
\text { subdimension } \\
\text { scores: } \\
10-7=\text { good } \\
7-5=\text { fair } \\
5-0=\text { poor }\end{array}$} & \\
\hline & 113. Menu Planning & $\begin{aligned} 10 & =\text { good } \\
5 & =\text { fair } \\
0 & =\text { poor }\end{aligned}$ & & & \\
\hline & 114. Food Safety & $\begin{aligned} 10 & =\text { good } \\
0 & =\text { poor }\end{aligned}$ & & & \\
\hline & 115. Regional Foods and Recipes & $10=$ good & & & \\
\hline & $\begin{array}{l}\text { 116. Preference for Family-Grown } \\
\text { Ingredients }\end{array}$ & $\begin{array}{l}5=\text { fair } \\
0=\text { poor }\end{array}$ & & & \\
\hline & 117. Number of Meals Served & $\begin{array}{r}10=\text { good } \\
0=\text { poor }\end{array}$ & & & \\
\hline & 118. User Satisfaction & $\begin{aligned} 10 & =\text { good } \\
5 & =\text { fair } \\
0 & =\text { poor }\end{aligned}$ & & & \\
\hline & S5. Food and Nutrition Education & & \multirow{2}{*}{$\begin{array}{l}\text { Indicator score: } \\
10-7=\text { good } \\
7-5=\text { fair } \\
5-0=\text { poor }\end{array}$} & & \\
\hline & $\begin{array}{l}\text { 119. Education in Food and } \\
\text { Nutrition and Food Security }\end{array}$ & $\begin{aligned} 10 & =\text { good } \\
5 & =\text { fair } \\
0 & =\text { poor }\end{aligned}$ & & & \\
\hline & S6. Extended Social Support & & \multirow{6}{*}{$\begin{array}{l}\text { Mean of indicator scores: } \\
10-7=\text { good } \\
7-5=\text { fair } \\
5-0=\text { poor }\end{array}$} & & \\
\hline & $\begin{array}{l}\text { 120. Promotion of other Social } \\
\text { Assistance Initiatives }\end{array}$ & $\begin{aligned} 10 & =\text { good } \\
0 & =\text { poor }\end{aligned}$ & & & \\
\hline & $\begin{array}{l}\text { 121. Local Food and Nutrition } \\
\text { Security Index }\end{array}$ & & & & \\
\hline & 122. Socialization Activities & $\begin{aligned} 10 & =\text { good } \\
5 & =\text { fair } \\
0 & =\text { poor }\end{aligned}$ & & & \\
\hline & 123. Intersectoral Actions & \multirow{2}{*}{$\begin{aligned} 10 & =\text { good } \\
0 & =\text { poor }\end{aligned}$} & & & \\
\hline & $\begin{array}{l}\text { I24. Visibility of the Government- } \\
\text { Subsidized Restaurants }\end{array}$ & & & & \\
\hline
\end{tabular}

Note: D: Dimension; S: Subdimension; I: Indicator. Example: S1: Subdimension 1. 
Table 2. Distribution of government-subsidized restaurants in southern Brazil according to their scores in the subdimensions and indicators of the Government-Subsidized Restaurant Evaluation Matrix. Florianópolis (SC), Brazil, 2020.

\begin{tabular}{|c|c|c|c|}
\hline \multirow{2}{*}{ Subdimension/Indicator } & \multicolumn{3}{|c|}{ Score category } \\
\hline & Good $(\%)$ & Fair (\%) & Poor $(\%)$ \\
\hline S1. Management & 63 & 30 & 7 \\
\hline 11. Availability & 10 & 90 & 0 \\
\hline 12. Human Resources & 37 & 50 & 13 \\
\hline 13. Financial Resources & 100 & 0 & 0 \\
\hline 14. Meal Price & 33 & 50 & 17 \\
\hline 15. Articulation with other Food and Nutrition Security Programs & 60 & 0 & 40 \\
\hline 16. Waste Management & 70 & 10 & 20 \\
\hline 17. Quality Assessment and Monitoring & 87 & 0 & 13 \\
\hline S2. Structure & 0 & 97 & 3 \\
\hline 18. Location & 97 & 0 & 3 \\
\hline 19. Physical Structure & 90 & 10 & 0 \\
\hline 110. Maintenance & 0 & 0 & 100 \\
\hline S3. Target Groups & 43 & 30 & 27 \\
\hline 111. Users & 43 & 0 & 57 \\
\hline 112. Prioritization of Specific Populations & 73 & 0 & 27 \\
\hline S4. Meal Quality & 70 & 27 & 3 \\
\hline 113. Menu Planning & 80 & 20 & 0 \\
\hline 114. Food Safety & 93 & 0 & 7 \\
\hline 115. Regional Foods and Recipes & 83 & 10 & 7 \\
\hline 116. Preference for Family-Grown Ingredients & 70 & 0 & 30 \\
\hline 117. Number of Meals Served & 90 & 0 & 10 \\
\hline 118. User Satisfaction & 20 & 7 & 73 \\
\hline S5. Food and Nutrition Education & 37 & 16 & 47 \\
\hline 119. Education in Food and Nutrition and Food Security & 37 & 17 & 47 \\
\hline S6. Extended Social Support & 13 & 47 & 40 \\
\hline 120. Promotion of other Social Assistance Initiatives & 67 & 0 & 33 \\
\hline 121. Local Food and Nutrition Security Index & 37 & 0 & 63 \\
\hline 122. Socialization Activities & 7 & 3 & 90 \\
\hline 123. Intersectoral Actions & 63 & 0 & 37 \\
\hline 124. Visibility of the Government-Subsidized Restaurants & 73 & 0 & 27 \\
\hline
\end{tabular}

Note: D: Dimension; S: Subdimension; I: Indicator. Example: S1: Subdimension 1.

The Structure (S2) subdimension had a high number of GSR ranked as good on two of the three indicators. Location (18) and Physical structure (19) received good scores in $97 \%$ and $90 \%$ of the GSR, respectively. However, $100 \%$ of the GSR had a poor score on Maintenance (110), the third indicator (Table 2). The subdimension Target groups (S3) is composed of two indicators, Prioritization of Specific Populations (112), on which 73\% of the GSR had a good score, and Users (111), on which $57 \%$ of the establishments had a poor score (Table 2 ).

In the subdimension Meal quality (S4), 90\% of the GSR ranked good for Food Safety (114) (93\%) and Number of Meals Served (117) (90\%). The indicator with the worst score was User Satisfaction (118); 73\% of the establishments received a poor score (Table 2). The subdimension Food and Nutrition Education (S5) has only one indicator, Education in Food and Nutrition and Food Security (119). This indicator was ranked as good in $37 \%$ of the GSR, fair in $16 \%$, and poor in 47\% (Table 2). The subdimension Extended Social Support (S6) achieved high scores because of the indicator Visibility of Government-Subsidized Restaurants (124), classified as good in 73\% of GSR. The lowest-scoring indicator was Socialization Activities (I22), on which $90 \%$ of the GSR had a poor score (Table 2). 
Overall, $70 \%$ or more of the GSR had a good score on $50 \%$ of the indicators and a poor score on only $6.7 \%$ of the indicators. The highest-ranked subdimensions were Administration (S1) and Meal Quality (S4), on which the percentage of GSR evaluated as good amounted to $63 \%$ and $70 \%$, respectively. The lowest-scoring subdimensions were Food and Nutrition Education (S5) (47\% of poor scores) and Extended Social Support (S6) (40\% of poor scores) (Table 2).

\section{DISCUSSION}

Government-Subsidized Restaurants and similar food programs are aimed at minimizing inequality in access to food. Although they may not immediately and profoundly change the social conditions of their users [7], GSR are a necessary and crucial part of the daily lives of many. In Brazil, despite advances in policies and programs aimed at reducing social inequalities, hunger and food and nutrition insecurity are pervasive problems. Research has shown that these conditions are strongly associated with socioeconomic status, level of education, and place of residence [14]. GSR in Brazil and other countries are designed to deal with social vulnerability and socioeconomic problems specific to the region.

Among the GSR evaluated in this study, $40 \%$ outsourced management or had a mixed management system. Research on the outsourcing of public services to private and third sector organizations, although incipient, is important to understand the effects of this form of privatization on the quality of public services. Regulation on GSR defines that, if food production is outsourced, the government must monitor service quality and meal price [10]. Further research on the effects of the management system on the quality of GSR is needed.

Most GSR were inaugurated between 2003 and 2010, a period in which the government was concerned about programs aimed at increasing food access and agriculture production [8]. The intersectionality between GSR and public food procurement valorized family agriculture through the purchase of local, family-grown ingredients. GSR have the potential to strengthen food production and culture, encourage agroecological management practices, preserve regional biodiversity, and stimulate the local economy [10].

Government-Subsidized Restaurants scored highest on the subdimensions Management (S1) and Meal Quality (S4), confirming their potential to ensure adequate food for their users, many of which depend entirely on these spaces to have at least one full meal a day [5]. A study conducted with 374 users of 8 community kitchens in Lima, Peru, highlighted the importance of ensuring the nutritional adequacy of meals. Because target population groups include people experiencing different levels of poverty and food insecurity, meals must contribute to meeting the daily nutritional requirements of users [15].

Extended Social Support (S6) and Food and Nutrition Education (S5) received the worst scores, indicating the limitation of GSR in promoting emancipation through the exercise of a right. As public facilities of food and nutrition security, GSR should go beyond welfarism and provision of a balanced, affordable meal [7]. These spaces must minimize the harmful effects of food insecurity and allow vulnerable groups to exercise their citizenship [16].

It is known that financial resources are needed to maintain high-quality social programs and meet the demands of the population [7]. All GSR scored high on the indicator Financial Resources (I3); managers reported that the programs have received a sufficient amount of resources since their implementation. However, the reality of southern Brazil is not necessarily the same as that 
of other regions of the country. Only $13.5 \%$ of Brazilian municipalities claim to have sufficient resources to maintain PNSAN public facilities [17]. As there is no direct transfer of federal resources to these programs, only decentralized resource allocation [17], the results suggest a great interest and commitment of municipalities in maintaining GSR with their resources. In other countries, as in the case of Mexico, food programs require resources from the federal government and, facing insufficient support, they may be temporarily closed [18]. As a strategy to achieve financial stability, Peruvian food programs were decentralized. Now, community kitchens in Peru are financed exclusively by municipal or state bodies $[15,19]$.

Most GSR scored high on the Prioritization of Specific Populations (112), indicating improved access of the most vulnerable population groups to adequate food. As a public facility of food and nutrition security, GSR are not only seen as food-producing units but also as strategies to ensure the right to adequate meals. The performance of GSR is not only related to low price or good meal quality but also to their guaranteed continuity, high coverage, and interaction with other PNSAN programs [7]. In Canada, the intersectionality of community food programs with food banks, soup kitchens, and social care services is evidence of the understanding of food and nutrition insecurity as a complex, multicultural, and socioeconomic challenge. Accordingly, these programs use cross-sectoral partnerships to help ensure the social, cultural, financial, and health equity of the population [2].

Some studies assessed household food insecurity in GSR users using the Brazilian Scale of Food Insecurity (EBIA) $[20,21]$. However, to effectively evaluate GSR as food and nutrition security facilities, several dimensions of different socio-organizational levels need to be analyzed. Researchers have suggested using the EBIA scale in conjunction with other indicators to expand evaluation beyond household variables in analyzing access to food [22]. GSR are also aimed at improving the health of users. Therefore, it is significant to monitor the impact of meals on users' health, assess whether resources are adequately managed, and determine the impact of the program on the lives of vulnerable people, especially in times of increasing poverty [22].

Local Food and Nutrition Security Index (I21) and User Satisfaction (124) received low scores. These data suggest that GSR do not appropriately assess and monitor their performance. Monitoring indicators is of great importance because it allows to understand the adjustments needed to improve service quality [5]. Balam-Gómez et al. [18] interviewed 177 users and 41 workers of three community kitchens in Mexico in 2011 and observed that the programs lacked the technical and methodological tools to estimate their contribution to improving the food security of users. Another Mexican study, evaluating three community kitchens with 395 users in 2016, reported that $50 \%$ of users experienced low levels of food insecurity. However, the authors observed that the programs did not perform an initial assessment of the level of food security of first-time users, which makes it impossible to determine the efficiency of the program in improving food security levels [5].

The users' view and opinion of the GSR is an important measure of effectiveness. A study interviewing 95 users of three community kitchens in Mexico showed that most users $(90 \%)$ were not evaluated for weight, nutrition status, or health, nor were they asked about the program or its impact on their lives [21]. The participation of users in the planning, monitoring, and evaluation of GSR allows for knowledge-based decision making and feedback on quality [21].

Social protection systems are essential tools in the fight against hunger. Their efficiency in promoting health, education, nutrition, and autonomy, however, depends on the involvement of different sectors of the government and society [5]. Intersectionality is a central element of PNSAN; it 
relies on a strong association between different public policies and government sectors to guarantee the human right to food $[5,23]$. For some GSR, cross-sectoral partnerships promoted the development of the local community by generating employment and stimulating local agricultural production [24].

However, the Articulation with other Food and Nutrition Security Programs indicator (15), identified $40 \%$ of establishments with poor performance. The intersectionality of the GSR contemplate actions related to the production, commercialization, supply, access and consumption of food. GSR incorporate all these actions on a daily basis, from the acquisition of food produced in family-based farming systems to the correct use of their organic waste [11]. An important example is the interaction between the GRS and the Food Acquisition Program, integrating two important populations: the users of the GRS and the producers of family farming. This relationship directly fosters important focuses of social policy, namely, social development, encouraging family farming and access to quality food for the most vulnerable individuals. It also contributes to generating jobs in the countryside, reducing the rural exodus and the poverty rate in the rural population [25].

Intersectionality can also be guaranteed through food and nutrition education actions that encourage users to have healthy eating habits and exercise their citizenship and their right to food [7]. However, in the analyzed GSR, a low frequency of educational actions was observed. Such actions could promote health and healthy eating habits in various population groups [7]. Education actions that take into consideration the socioeconomic status of users can help build bonds through learning [11]. A study carried out with 123 users of Peruvian community kitchens between 2004 and 2005 highlighted that food assistance programs should be used to introduce interventions aimed at improving the eating habits of users by teaching cooking skills and food and nutritional quality information [5].

Moreover, food and nutrition education can reinforce the human right to food. Knowledge and awareness of this right by the general population might help change the image of GSR and similar public policies and increase the access of people to a dignified life, without restrictions $[12,16,26,27]$. According to Buttorff et al., GSR in low-income municipalities should be a place for food and nutrition education as part of a broader strategy to combat lifestyle-related diseases [6].

We emphasize the need to adapt Brazilian regulations on GSR to PNSAN and the reality of small municipalities. Most GSR were located in small municipalities and thus were not able to comply with guidelines aimed at metropolises. More efficient decentralization mechanisms are needed to incorporate GSR into municipal frameworks.

Advances in evaluation methods that consider food security as the basis of GSR are needed. Through efficient monitoring, it is possible to ensure that the program achieves its objectives more efficiently and effectively [5] By considering GSR as an intersectoral element of PNSAN, decisionmakers can use them as effective tools to fulfill the right to food [5].

\section{CONCLUSION}

Government-Subsidized Restaurants in southern Brazil are important elements of PNSAN and play a crucial role in ensuring food and nutrition security and the right to food to vulnerable populations. Almost all GSR in operation in southern Brazil participated in this study and scored high on variables related to management, structure, and meal quality. However, unsatisfactory results were obtained regarding indicators that define GSR as welfare programs and public facilities of food 
security. Greater awareness is needed on the important role of these programs as well as efficient monitoring tools to evaluate (and increase) the potential of GSR in fulfilling the right to food.

As a limitation of this study, we highlight its regional character, since only the GSR located in southern Brazil, comprising three states, were evaluated. However, as the evaluation matrix is flexible, it can be successfully applied in other regions of the country. Other variables and indicators can be incorporated to adapt the tool to the context of each GSR. Thus, our results may stimulate the evaluation of other establishments.

The normative evaluation is based on the strong relationship between respect for the criteria and norms chosen and the real effects of the program. Therefore, the potential of this evaluation is to identify activities and actions that can be improved on the intervention, optimizing and improving it. However, it may present itself as a limitation in this study, due to the aforementioned outdating of existing regulations.

This study presents current and relevant data that can be useful to other countries with similar programs, especially those with a large number of people experiencing vulnerability. Each country, according to the local context, must evaluate and improve these public facilities to expand their potential to fulfill the human right to adequate food.

\section{CONTRIBUTORS}

JTC OLIVEIRA participated in the conception, design, analysis, interpretation of data, and writing the article. CG GABRIEL, ML MACHADO, C SOAR, and A FAGUNDES participated in the conception, design, review, and final approval of the article. FAG VASCONCELOS participated in the conception, review, and final approval of the article.

\section{REFERE N CES}

1. Organización de las Naciones Unidas para la Alimentación y la Agricultura. Panorama de la seguridad Alimentaria y Nutricional en América Latina y el Caribe. Santiago: Organización; 2019 [citado 20 abr 2020]. Disponible en: http://www.onu.org.mx/publicaciones/panorama-de-la-seguridad-alimentaria-y-nutricionalen-america-latina-y-el-caribe-2019/

2. Pettes T, Dachner N, Gaetz S, Tarasuk V. An examination of charitable meal programs in five Canadian cities. J Health Care Poor Underserved. 2016;27(3):1303-15. https://doi.org/10.1353/hpu.2016.0121

3. Koh KA, Bharel M, Henderson DC. Nutrition for homeless populations: shelters and soup kitchens as opportunities for intervention. Public Health Nutr. 2016;19(7):1312-4. https://doi.org/10.1017/S13689800 15002682

4. Kraemer, FB, Arnaiz, MG. Alimentarse o nutrirse en un comedor social en España: reflexiones sobre la comensalidad. Demetra. 2015;10(3):455-66. https://doi.org/10.12957/demetra.2015.16173

5. Caro FB, Hernández EYR, Fajardo, KDG, Veveros SS, Torres RM. Nivel de Seguridad Alimentaria en beneficiarios de Comedores Comunitarios del programa Cruzada Nacional contra el Hambre (México). Rev Esp Nutr Comunitaria. 2018 [citado 20 abr 2020];24(3). Disponible en: https://dialnet.unirioja.es/servlet/ articulo?codigo $=6930057$

6. Buttorff C, Trujillo AJ, Diez-Canseco F, Bernabe-Ortiz A, Jaime Miranda J. Evaluating consumer preferences for healthy eating from Community Kitchens in low-income urban areas: a discrete choice experiment of Comedores Populares in Peru. Soc Sci Med. 2015;140:1-8. https://doi.org/10.1016/j.socscimed.2015.06.033

7. Padrão SM, Aguiar OB. Restaurante popular: a política social em questão. Physis: Rev Saúde Coletiva. 2018;28:e280319. https://doi.org/10.1590/\$0103-73312018280319 
8. Tomazini CG, Leite CKS. Programa Fome Zero e o paradigma da segurança alimentar: ascensão e queda de uma coalizão? Rev Sociol Polit. 2016;24(58):13-30. https://doi.org/10.1590/1678-987316245801

9. Ministério do Desenvolvimento Social e Combate à Fome (Brasil). Mapeamento da Segurança Alimentar e Nutricional. Brasília: Ministério; 2015 [citado 20 abr 2020]. Disponível em: http://www.dados.gov.br/dataset/ mapeamento-de-seguranca-alimentar-e-nutricional

10. Ministério do Desenvolvimento Social e Combate à Fome (Brasil). Manual Programa Restaurante Popular. Brasília: Ministério; 2004 [citado 20 abr 2020]. Disponível em: http://bvsms.saude.gov.br/bvs/publicacoes/ projeto_logico_restaurante_popular.

11. Oliveira J, Gabriel C, Machado M, Réos M, Soar C, Venske D. Restaurantes Populares enquanto promotores da realização do Direito Humano à Alimentação Adequada: proposição de um modelo avaliativo. Rev Nutr. 2019;32:e180193. https://doi.org/10.1590/1678-9865201932e180193

12. Branquinho A, Oliveira, KES, Akutsu RC, Silva EF. Sociodemographic and health profile of clients of community restaurants of Brazilian social programs. Rev Chin Nutr. 2015;42(1):14-22. https://doi.org/10.4067/S071775182015000100001

13. Instituto Brasileiro de Geografia e Estatística. Pesquisa Nacional por Amostra de Domicílio: Segurança Alimentar (PNAD/2013). Brasília: Instituto; 2014. [ccitado 20 abr 2020]; Disponível em: https://www.ibge. gov.br/estatisticas/sociais/educacao/9127-pesquisa-nacional-por-amostra-de-domicilios.html

14. Anjos FS, Caldas NV. Inovações no combate à fome e à insegurança alimentar. Rev Est Bra. 2018 [citado 20 abr 2020];5(10):11-24. Disponível em: https://www.revistas.usp.br/reb/article/view/154307

15. Adams K, Chirinos J. Prevalence of risk factors for metabolic syndrome and its components in community kitchen users in a district in Lima, Peru. Rev Peru Med Exp Salud Publica. 2018;35(1):39. https://doi. org/10.1038/srep38089

16. Gomes MFS, Pereira SCL, Abreu MNS. Fatores associados à autopercepção de saúde dos idosos usuários dos restaurantes populares de Belo Horizonte. Ciênc Saúde Colet. 2018;23:4007-19. https://doi.org/10. 1590/1413-812320182311.31072016

17. Vasconcellos ABPA, Moura LBA. Segurança alimentar e nutricional: uma análise da situação da descentralização de sua política pública nacional. Cad Saúde Pública. 2018;34:e00206816. https://doi.org/10.1590/0102-3 $11 \times 00206816$

18. Balam-Gómez M, Uicab-Pool G, Uch-Puc P, Sabido-Barrera J. Evaluación de los comedores comunitarios en Tizimín, Yucatán, México: percepciones y propuestas del personal y beneficiarios. Enferm Univ. 2013;10(4):125-32. https://doi.org/10.1016/S1665-7063(13)72641-1

19. Paredes-Aramburú J, Bernabé-Ortiz A. Asociación entre la participación en programas de asistencia alimentaria y patrones del perfil lipídico en Perú. Ver Chi Nutr. 2018;45(2):135-43. https://doi.org/10.4067/ s0717-75182018000300135

20. Falcão ACML, Aguiar OBD, Fonseca MDJMD. Association of socioeconomic, labor and health variables related to food insecurity in workers of the Popular Restaurants in the city of Rio de Janeiro. Rev Nutr. 2015;28(1):77-87. https://doi.org/10.1590/1415-52732015000100007

21. Ribeiro AA, Pessoa MTG, Azevedo SMU, Oliveira VTL, Meireles AL. Caracterização socioeconômica, estado nutricional e prevalência de insegurança alimentar em idosos usuários do restaurante popular de um município do nordeste brasileiro. Rev Ciênc Plural. 2016[citado 20 abr 2020];2(3):59-71. Disponível em: https://periodicos.ufrn.br/rcp/article/view/11051

22. Martínez CEA, Castillo VL, Méndez MID. Análisis crítico del discurso: las mujeres en el programa Comedores Comunitarios, México. Opción. 2016[citado 20 apr 2020];32(13). Disponible em: https://dialnet.unirioja.es/ servlet/articulo?codigo $=5844662$

23. Silva DAS, Panelli-Martins BE. O processo de adesão municipal ao Sistema Nacional de Segurança Alimentar e Nutricional. Segur Aliment Nutr. 2020;27:e020006. https://doi.org/10.20396/san.v27i0.8655377

24. Zanini E, Schneider MB. Restaurantes populares em Toledo: um programa de desenvolvimento. Econ Desenvol. 2016;27(2). https://doi.org/10.5902/1414650920984

25. Schneider MB, Costa FF. Impacto dos restaurantes populares na saúde e no desenvolvimento social dos usuários: o caso de Toledo (PR). Redes (St Cruz Sul online). 2019;24(1):310-34. https://doi.org/10.17058/ redes.v24i1.9672 
26. Assunção RCLN, Bastos PV, Silva BPL, Percegoni N, Mendes LL, Pinoti NL. Perfil socioeconômico, demográfico e alimentar dos usuários do restaurante popular de Juiz de Fora, MG. Demetra. 2017;12(1):289-304. https:// doi.org/10.12957/demetra.2017.23577

27. Bento IC, Filgueiras JH, Abreu MNS, Pereira SCL, Gazzinelli MF. Fatores associados às fases de comportamento alimentar de usuários dos restaurantes populares em Belo Horizonte/MG-Brasil. Rev Port Saúde Pública. 2016;34(3):283-91. https://doi.org/10.1016/j.rpsp.2016.06.006

Approved: August 18, 2020 